2005-2267

\title{
Successful Research Experience for Undergraduates Program (REU) - The ERC for Reconfigurable Manufacturing Systems
}

\author{
ELIJAH KANNATEY-ASIBU, JR. \\ Yoram Koren \\ Lenea Howe \\ Engineering Research Center for Reconfigurable Manufacturing Systems \\ University of Michigan \\ Ann Arbor, Michigan 48109
}

\begin{abstract}
The National Science Foundation Engineering Research Center for Reconfigurable Manufacturing Systems (ERC/RMS) was awarded an NSF grant for a Research Experience for Undergraduates (REU) program in 1997. The goal of the ERC in seeking funding for the project was to increase the number of underrepresented minority students in graduate school and to serve as a model for diversity within the University of Michigan community and the nation as a whole.

The ERC has been very successful in involving young and promising cadres of underrepresented minority undergraduate students in this summer research experience, introducing them to the rigors of graduate school, and later, watching their graduate school applications arrive. The key elements to the success of the REU program in the ERC/RMS are: a team research project in reconfigurable manufacturing, a series of workshops, and a graduate school/GRE preparation program.
\end{abstract}

\section{Introduction}

The National Science Foundation (NSF) funds a large number of research opportunities for undergraduate students through its REU Sites program. An REU Site consists of a group of about ten undergraduates who work in the research programs of the host institution. Each student is associated with a specific research project, where he/she works closely with the faculty and other researchers. Students are granted stipends and, in many cases, assistance with housing and travel. Undergraduate students supported with NSF funds must be citizens or permanent residents of the United States or its possessions. An REU Site may be at either a US or foreign location. The program seeks to attract a diversified pool of talented students into careers in science and engineering and to help ensure that they receive the best education possible.

For the sake of clarity, the following definitions are being inserted: REU - Research Experience for Undergraduates, NSF supported CIC - Committee for Institutional Cooperation - an academic consortium of the Big 10 Universities and the University of Chicago. All CIC colleges offer an SROP program. 
SROP - Summer Research Opportunity Program

\section{Program Goal}

The goal of the Research Experience for Undergraduates (REU) is to motivate promising students who are currently underrepresented in the field of engineering to seriously consider graduate education, to give them a research opportunity that they might not have at their home institution, and to help prepare them for admission to graduate school. The program was designed to enhance diversity in graduate programs and thereby the number of students going to industry or academia with advanced degrees.

\section{Rackham's Role}

We are fortunate to be able to collaborate with the Rackham Graduate School (Rackham) at $U$ of M as part of our REU program. The Summer Research Opportunity Program (SROP) administered by Rackham, is a parallel program to the REU. We are able to take advantage of their existing programming to add value to the REU.

Rackham generally accepts 50 students in their SROP program which includes our REU students. Typically, our REU group consists of eight students. Rackham includes our students along with theirs when making flight reservations, room reservations, scheduling for the GRE preparation class and when planning their evening speaker series. In addition, all of the students visit another Big-10 college campus in July where they present the essence of their research. The ERC participates in the different facets of the program with Rackham since the additional programming creates a stronger overall summer experience for our REU students. The REU students therefore interact effectively with the SROP students all summer, which adds a strong social element. The ERC/RMS provides the research component and the classes, workshops and engineeringrelated field trips for the research element of the summer experience.

The Rackham Graduate School belongs to the Committee for Institutional Cooperation (CIC) which includes the Big 10 Conference Universities as well as the University of Chicago. The CIC was awarded the prestigious Presidential Award for Excellence in Science, Mathematics, and Engineering Mentoring in 2002. Awardees of this designation are leaders in the national effort to train the next century of scientists, mathematicians and engineers.

\section{History}

The ERC/RMS was awarded an REU grant in 1997 and the Center has continued to be funded for this program to date. Since that time, sixty students have participated in the 8 -week summer research program.

\section{STUDENT PARTICIPANT SUMMARIES}

1997

\begin{tabular}{|l|l|l|l|l|}
\hline Gender & Ethnicity & $\begin{array}{l}\text { Program of } \\
\text { Study }\end{array}$ & Undergraduate School & $\begin{array}{l}\text { Year Entering } \\
\text { in Fall }\end{array}$ \\
\hline F & AA & IOE & Clark Atlanta University & Senior \\
\hline
\end{tabular}




\begin{tabular}{|c|c|c|c|c|}
\hline $\mathrm{M}$ & AA & $\mathrm{ME}$ & Clark Atlanta & Senior \\
\hline $\mathrm{M}$ & Other & $\mathrm{CS}$ & Dillard University & Senior \\
\hline \multicolumn{5}{|l|}{1998} \\
\hline Gender & Ethnicity & $\begin{array}{l}\text { Program of } \\
\text { Study }\end{array}$ & Undergraduate School & $\begin{array}{l}\text { Year Entering } \\
\text { in Fall }\end{array}$ \\
\hline $\mathrm{F}$ & PR & IOE & U of PR Mayaguez & Senior \\
\hline $\mathrm{M}$ & PR & $\mathrm{ME}$ & U of PR Mayaguez & Junior \\
\hline $\bar{M}$ & PR & $\mathrm{CS}$ & U of PR Mayaguez & Senior \\
\hline $\mathrm{M}$ & AA & $\mathrm{CS}$ & Dillard University & Sophomore \\
\hline \multicolumn{5}{|l|}{1999} \\
\hline Gender & Ethnicity & $\begin{array}{l}\text { Program of } \\
\text { Study }\end{array}$ & Undergraduate School & $\begin{array}{l}\text { Year Entering } \\
\text { in Fall }\end{array}$ \\
\hline $\mathrm{F}$ & AA & Physics & Jackson State University & Senior \\
\hline $\mathrm{F}$ & PR & IOE & U of PR Mayaguez & Sophomore \\
\hline $\mathrm{F}$ & AA & Physics & Dillard University & Junior \\
\hline $\mathrm{M}$ & PR & ME & U of PR Mayaguez & Senior \\
\hline \multicolumn{5}{|l|}{2000} \\
\hline Gender & Ethnicity & $\begin{array}{l}\text { Program of } \\
\text { Study }\end{array}$ & Undergraduate School & $\begin{array}{l}\text { Year Entering } \\
\text { in Fall }\end{array}$ \\
\hline $\mathrm{M}$ & PR & $\mathrm{ME}$ & U Polytech de PR & Junior \\
\hline $\mathrm{M}$ & NA & Engn Tech & Univ of New Mexico & Junior \\
\hline $\mathrm{F}$ & AA & CS & Mississippi Valley State U & Junior \\
\hline $\mathrm{F}$ & $\mathrm{W}$ & $\mathrm{CS}$ & Woodbury University & Senior \\
\hline $\mathrm{F}$ & AA & $\mathrm{CS}$ & Cheyney University & Sophomore \\
\hline $\mathrm{M}$ & NA & ME & Oklahoma State University & Senior \\
\hline $\mathrm{F}$ & Other & Engn & UCLA & Sophomore \\
\hline $\mathrm{F}$ & Other & $\mathrm{ME}$ & UCLA & Sophomore \\
\hline $\mathrm{F}$ & AA & Civil & North Carolina A\&T Univ & Senior \\
\hline $\mathrm{F}$ & PR & IOE & U Polytech de PR & Junior \\
\hline $\mathrm{F}$ & AA & Civil & North Carolina A\&T Univ & Junior \\
\hline $\mathrm{M}$ & AA & $\mathrm{CS}$ & Morehouse University & Sophomore \\
\hline \multicolumn{5}{|l|}{2001} \\
\hline Gender & Ethnicity & $\begin{array}{l}\text { Program of } \\
\text { Study }\end{array}$ & Undergraduate School & $\begin{array}{l}\text { Year Entering } \\
\text { in Fall }\end{array}$ \\
\hline $\mathrm{M}$ & $\mathrm{AA}$ & $\mathrm{ME}$ & North Carolina A\&T Univ & Sophomore \\
\hline $\mathrm{F}$ & AA & CSE & Georgia Tech & Sophomore \\
\hline $\mathrm{M}$ & $\mathrm{H}$ & ME & Georgia Tech & Junior \\
\hline F & AA & EE & Fisk University & Sophomore \\
\hline M & AA & $\mathrm{EE}$ & Howard University & Junior \\
\hline F & $\mathrm{H}$ & Math & New Mexico State Univ & Sophomore \\
\hline $\mathrm{F}$ & $\mathrm{W}$ & CSE & Sweetbriar College & Junior \\
\hline $\mathrm{F}$ & PR & IOE & U of PR Mayaguez & Junior \\
\hline $\mathrm{F}$ & NA & EE & North Carolina A\&T Univ & Sophomore \\
\hline \multicolumn{5}{|c|}{ 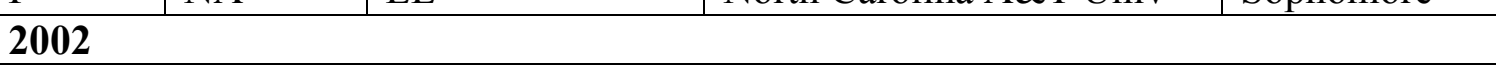 } \\
\hline Gender & Ethnicity & Program of & Undergraduate School & Year Entering \\
\hline
\end{tabular}

"Proceedings of the 2005 American Society for Engineering Education Annual Conference \& Exposition Copyright@2005,American Societyfor Engineering Education” 


\begin{tabular}{|l|l|l|l|l|}
\hline & & Study & & in Fall \\
\hline M & AA & Civil & Southern University & Senior \\
\hline F & AA & EE & Alabama A\&M University & Senior \\
\hline F & NA & Physics & E. Central Oklahoma U & Senior \\
\hline F & Asian & ME & U of CA Riverside & Senior \\
\hline F & AA & CSE & Tougaloo University & Senior \\
\hline F & Asian & CSE & San Francisco State Univ & Senior \\
\hline F & W & ME & Saginaw Valley State Univ & Senior \\
\hline M & AA & Physics & Fisk University & Senior \\
\hline F & AA & Chem E & Tuskegee University & Senior \\
\hline
\end{tabular}

2003

\begin{tabular}{|l|l|l|l|l|}
\hline Gender & Ethnicity & $\begin{array}{l}\text { Program of } \\
\text { Study }\end{array}$ & Undergraduate School & $\begin{array}{l}\text { Year Entering } \\
\text { in Fall }\end{array}$ \\
\hline M & AA & Math & Delaware State University & Junior \\
\hline F & AA & CS & Jackson State University & Junior \\
\hline F & AA & CS & Tuskegee University & Senior \\
\hline M & AA & CS & U of Maryland Baltimore & Sophomore \\
\hline M & AA & CS & Xavier University & Junior \\
\hline F & AA & Info Systems & U of Maryland Baltimore & Junior \\
\hline F & W & Education & $\begin{array}{l}\text { Eastern Michigan } \\
\text { University }\end{array}$ & Senior \\
\hline M & AA & CS & Xavier & Junior \\
\hline M & AA & IOE & Morgan State University & Junior \\
\hline F & AA & CS & Tougaloo University & Sophomore \\
\hline F & PR & IOE & U of PR Mayaguez & Senior \\
\hline F & AA & CS & Howard University & Junior \\
\hline M & AA & EE & Alabama A\&M University & Junior \\
\hline
\end{tabular}

\section{4}

\begin{tabular}{|l|l|l|l|l|}
\hline Gender & Ethnicity & $\begin{array}{l}\text { Program of } \\
\text { Study }\end{array}$ & Undergraduate School & $\begin{array}{l}\text { Year Entering } \\
\text { in Fall }\end{array}$ \\
\hline M & AA & IOE & Morgan State University & Junior \\
\hline F & AA & CS & Spelman Univesity & Junior \\
\hline M & AA & IOE & Morgan State University & Sophomore \\
\hline M & PR & IOE & U of PR Mayaguez & Junior \\
\hline F & PR & IOE & Polytech U de PR & Senior \\
\hline M & AA & ME & Alabama A\&M University & Sophomore \\
\hline
\end{tabular}

\section{REU Program Guidelines}

Our REU program is largely based on the Rackham SROP guidelines [Capsouras]:

- Participants must be US citizens or permanent residents from groups historically underrepresented in the Science, Technology, Engineering and Mathematics (STEM) fields. Students entering their junior or senior year are eligible to participate. Students must have a minimum 3.0 GPA in their major field and be strongly considering a PhD program after finishing their baccalaureate studies. 
- Students participate in the mentor's research. In some cases, a student may develop an independent research project with the mentor. In either case, the mentor participates fully in the design, implementation and evaluation of the research.

- Students are expected to work between 20 and 30 hours per week on their research project during the eight weeks of the program. Mentors may adjust the schedule as required to accommodate special programming.

- Students cannot enroll for summer term classes due to the time commitment of the program.

- Mentors and students are expected to meet regularly.

- Students are required to attend all SROP and REU scheduled activities as a condition of their participation in the program.

- Students receive a $\$ 4,000$ stipend, paid in two installments during the summer.

\section{Program Overview and Timeline}

- Each year, the program is initiated by updating and distributing program posters about eight months prior to the starting date of the program (October). Advertising posters are sent to Historically Black Colleges and Universities (HBCU's), Hispanic serving institutions, women's colleges and Tribal Colleges. In addition, posters are sent by email to colleagues at many universities around the country and to students who were past participants in the REU. The posters are mailed in January.

- In December, proposals are requested from graduate students wishing to work with the REU students the following summer. Between three and five proposals are received, and generally three are accepted. One of the strengths of our program is that we make the call for proposals a friendly competition in which the graduate students presenting the best proposals win prizes of $\$ 500, \$ 300$ and $\$ 200$ respectively.

- During the months of January and February the winning proposals are selected.

- February 10 is the deadline for receipt of REU application packages.

- Student selections are made by the Associate Director for Education and the Education Coordinator.

- Graduate student mentors (those with the winning project proposals) then select the students whose skills most closely match those of the prospective project. They call the students and discuss the project and ask for a commitment at that time.

- Students are then formally admitted by US mail.

- Graduate student mentors send any materials ahead of time that the students need to study before coming to campus.

- Travel arrangements are made.

- Students arrive on campus during the first week of June.

- June through July: see summer schedule.

- The last week of July students depart Ann Arbor.

\section{Advertising}

"Proceedings of the 2005 American Society for Engineering Education Annual Conference \& Exposition Copyright@2005,American Societyfor Engineering Education” 
Figure 1 shows the poster that is being used to advertise the 2005 program. A copy was sent to $200+$ schools along with a letter requesting that the recipient post in a prominent place for the undergraduate students to see. We also sent a poster to the last two years' participants in the program and asked that they advertise for us on their campus. In addition, the recruiters from the Rackham Graduate School distributed the posters during their recruitment trips to various college campuses. We sent posters via email to personal contacts at other universities and to our colleagues in other ERC's across the country. 


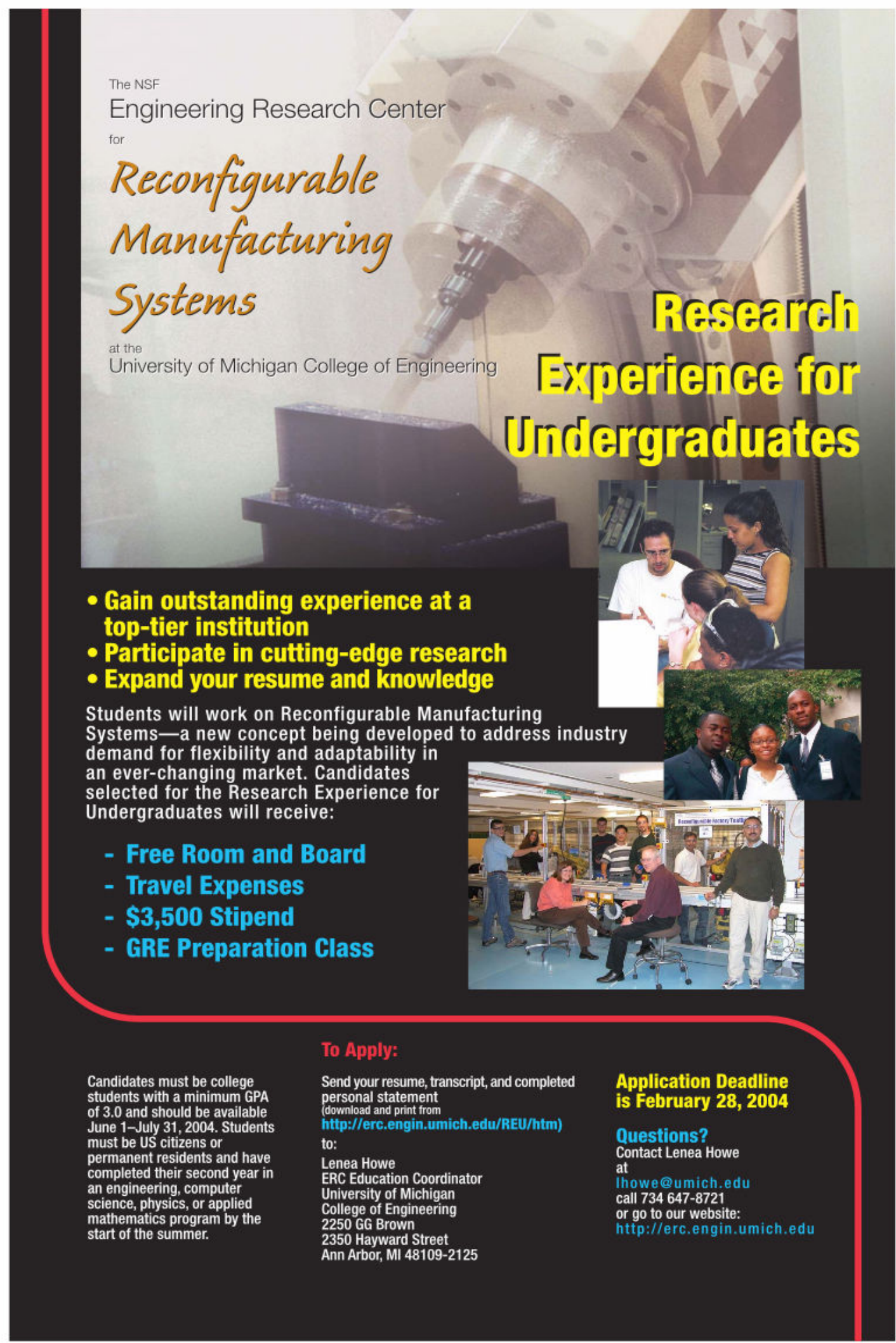

Figure 1

"Proceedings of the 2005 American Society for Engineering Education Annual Conference \& Exposition Copyright@ 2005, American Society for Engineering Education" 


\section{Call for Proposals}

A call for proposals is generated in November by sending an email to all graduate students, research scientists and faculty. In an email, projects are suggested that would be particularly good ones for summer students and work directly with those project leaders to gather the proposals. The prizes for the winning proposals are $\$ 500, \$ 300$ and $\$ 200$. In addition, the mentors for those three projects receive $\$ 1,500$ each for their extra work with the students during the summer.

\section{Participant Selection}

All applications are reviewed at the same time for admission into the REU program. If an application is not complete it is set aside until the necessary documents are received. Applicants finishing their freshman or senior year, or with a GPA lower than 3.0 are not considered. If a student is studying in a discipline far removed from one of the usual ones in the Center ( ME, IOE, Computer Science, EE, Math, Physics), the application is set aside for consideration later. What's left at that point is the active applicant pool. The applications are carefully evaluated and the Associate Director for Education informally matches up possible candidates for the different projects. At that point, the graduate student mentors look over the applications and make selections from those already chosen by the Associate Director. The mentors then call the applicants on the phone to discuss the projects, and if they all agree that there is a match, we ask for a commitment and send a commitment letter out right away.

\section{Typical Summer Calendar}

- June 1

- Students Arrive, Move Into Dorms

- Welcome and Dinner Reception

- June 2

- Photo ID's

- Ropes Challenge Course

- Seminar \#1: Setting Goals, Overcoming Challenges, Getting to Know Yourself

- Dinner and Group Discussions

- June 3

- Seminar \#2: Introduction and Orientation to the University

- First Stipend Payment

- Meet Your Faculty Luncheon

- Central Campus Tour

- June 4

- GRE-Pre-Test with Princeton Review

- Graduate Library and North Campus Tour

- June 5

- Cookout at Island Park 
- June 6

○ Holiday

- June 7

- ERC Orientation and Tour

- Research Group Meeting

- June 8

- GRE Class 1

- June 9

- Ford Rouge Plant Tour

- Seminar \#3: Research Ethics: Responsibility and Ethical Dilemmas in Academia

- June 10

- GRE Class 2

- June 11

- Friday Meeting

- REU/ERC-All Barbeque

- June 15

- GRE Class 3

- June 16

- Seminar \#4: Writing Your Graduate School Application Essay

- June 17

- GRE Class 4

- June 18

$\circ$ Friday Meeting

○ Engineering Ethics Workshop

- June 22

- GRE Class 5

- June 24

- GRE Class 6

○ Seminar \#5: Developing Your Abstract-Writing and Presentation Skills

- June 29

- GRE Class 7

- June 30

- Seminar \#6: Basic Components of the Graduate School Application Process 
- July 1

- GRE Class 8

- July 2

$\circ$ Friday Meeting

- July 5

$\circ$ Holiday

- July 6

- Seminar \#7: Workshop on Diversity

- July 8 - 11

- Depart for CIC Conference at University of Iowa

- July 13

- GRE Class 9

- July 14

- Seminar \#8

- Institutionalized Barriers to Underrepresented Populations in Higher Education

- Abstracts Due

- July 15

- GRE Class 10

- July 16

$\circ$ Friday Meeting

- July 20

- GRE Class 11

- Seminar \#9: Workshop on Career Options for PhD Graduates

- July 21

- Seminar \#10: Preparing for the Final Research Symposium

- July 22

- GRE Class 12

- Engineering Graduate School Seminar

- Social Hour with Society of Minority Engineering Students Graduate Component (SMES-G)

- July 26

- Seminar \#11: Selecting and Financing the Right Graduate Program for You 
- July 28

- Lunch with ME and IOE faculty and presentations of summer research

- July 29

○ Final Research Symposium

- July 30

- Residence Hall Check-Out

- Students Depart for Home

\section{Mentor Guidelines}

Since our REU program is organized in collaboration with the SROP program, our guidelines for mentors and students are based on the Rackham SROP mentor and student guidelines [Capsouras].

The relationship between the REU student and the project leader/mentor (faculty, member, research scientist or graduate student) is the foundation of the REU program. Mentors aid in one of the primary goals of the program: introducing students to the graduate school experience through a full range of applied research opportunities. Research and related projects may include reading primary literature, developing hypotheses, designing and carrying out experiments, studying and analyzing results and writing about research. Mentors are afforded a great deal of autonomy in developing a working and mentoring relationship with the student. However, the following serves as a guide:

- Spend substantial quality time with students, investing a suggested minimum of three hours per week.

- Give regular and constructive feedback to the students.

- Make yourself available to interact with the students by email, phone and in person.

- Create experiences that engage the student's technical expertise.

- Develop tasks that allow the students to use their academic skills.

- Try to involve the students in projects that relate to future coursework and career goals.

Successful partnerships require consistent and clear communication. Mentors must keep in mind that graduate-level research may be a new experience for some REU students. Students may be unclear about what is expected of them and about the tasks involved in completing a research project. Mentors need to clarify their expectations of the students from the very first meeting. It also helps to keep them informed of ongoing changes regarding the project. Here are some suggestions given to mentors:

- Set mutually agreed upon target dates for completion of specific tasks.

- Establish regular meeting times and work hours.

- Introduce students to other individuals who can help answer questions in their absence. This will broaden the team aspect of their experience.

- Make sure students have a multiple ways to contact you. 
Regularly scheduled meetings aid in communication and in assuring progress toward the student's final project goals. In addition to the weekly Friday meetings with the Associate Director, we recommend regular weekly meetings for the mentor and his students to assure progress toward the final project goals. During the weekly meeting, mentors have the opportunity to assess the student's ability to engage in independent work and offer feedback about work habits, work quality, strengths, and areas in need of improvement. Weekly meetings are also a great time to share personal reflections of the mentor's graduate school experience.

Throughout the duration of the program, students are asked to balance research hours with required GRE classes and seminars, field trips and workshops. Therefore, it is important for the mentors to determine the number of research hours they will require of the students each week along with a coordinated schedule. We recommend that the students work between 20 and 30 hours per week on their research project.

Although students accepted into the REU program are highly qualified academically, part of their experience includes developing the ability to work independently on research projects. Some students need to be guided through each step of the research process before they can begin. We suggest to mentors that they divide complex tasks into subtasks allowing better monitoring of the student's progress. A task list which the mentor and the student set up together will provide the student with a clear understanding of the project and necessary steps for completion. Eventually, the student should become comfortable and confident and work without supervision.

\section{Student Responsibilities}

Students are expected to make a full-time commitment to their research and to participate in all mandatory SROP and REU sponsored events. The events are coordinated so that there is no overlap.

- Research**

- Weekly SROP seminars*

- Orientation**

- Peer Group meetings*

- Manufacturing Plant Tour**

- Friday meetings with the Associate Director for Education**

- Two GRE preparation classes per week*

- Engineering Ethics workshop**

- Communications Workshop**

- Engineering Graduate School Seminar**

- Annual CIC/SROP Conference at a Big-10 University*

- Research Presentations to ME and IOE faculty**

- SROP Final Research Symposium to present their research project.*

*Mandatory for SROP program

**Mandatory for REU program 
Research: Students are expected to establish regular research hours and work between 20 and 30 hours per week on their projects. The number of hours per week will vary depending on special programming.

Weekly SROP Seminars: Weekly seminars are scheduled once each week after 4pm to address students' academic, personal, and professional development. Three themes are attended to in the series: Research Skills, Graduate School Application Process, and Personal Development/Institutional Views of Difference in the Academy.

Orientation: The Student Leadership Council (SLC) in the ERC prepares an in-depth orientation for the REU students. They create a slide presentation giving the history, mission, current research projects and outreach initiatives in the ERC. They take a tour of the testbed area and graduate students provide demonstrations of the various projects for the REU students. Orientation ends with a social time where the REU students can meet current ERC students, faculty, research scientists, staff and other students who are visiting the Center for the summer.

Peer Group Meetings: Each student is assigned to a graduate student coordinator and peer group. The peer group functions to share ideas, discuss experiences, and address skill development in a more intimate setting. The graduate student coordinator's role is to assist participants with creating and maintaining a valuable research partnership and a rewarding personal experience. In the advisor role, graduate student coordinators help students with skill development, time management, communication, and other concerns that might arise.

Manufacturing Plant Tour: The REU students, along with current students in the Center, board a University bus and visit the Ford Rouge Factory in Dearborn, Michigan. The students witness a manufacturing miracle where tons of iron ore, coal and sand pour into one side of the complex and polished F150 trucks roll off the assembly line on the other side of the factory the very next day. The plant tour is a very memorable event during the summer experience.

Friday Meetings: Every Friday during the summer the REU students have a standing meeting with the Associate Director for Education. At the meetings, students update the group on their research findings and practice presenting their work. It is the constant practice that makes the students very comfortable with the material and gives them a polished presence for the final symposium.

GRE Preparation Classes: All participants are required to take part in the GRE preparation class, which is funded by the Program and offered by the Princeton Review. Students must schedule time for two 3-hour classes per week. Students are evaluated through a series of practice tests and offered a GRE fee waiver pending improvement over the course of the class. The REU students consistently improve their scores by 200 points or better by the end of the session. 
Engineering Ethics Workshop: The ERC offers a very popular workshop on engineering ethics to provide the students with resources for understanding and addressing ethically significant problems that arise in their research and their work as professional engineers.

Communications Workshop: The communications workshop offered to the REU students each year includes communication skills involving poster making and presentations, writing abstracts and papers, resume and cover letter writing. The most popular portion of the workshop is a segment on best practices for presenting scientific material to various audiences.

Engineering Graduate School Seminar: At the beginning of the summer we ask the REU students what engineering department they are most interested in. Then we customize a graduate school seminar for the students which includes the graduate coordinators, faculty and graduate students from those departments who talk about the programs and student life at Michigan.

Annual CIC/SROP Conference at a Big-10 University: The Rackham SROP is embraced by several institutions belonging to the Committee on Institutional Cooperation (CIC). Each summer, all SROP programs associated with the CIC, gather to exchange research ideas, reflect on project experiences, and network. SROP students, along with the REU students, are required to give an oral presentation or their work to date at the conference. The conference is scheduled during a weekend halfway through the program, offering participants a benchmark of progress toward their final research presentations.

Research Presentations to ME and IOE Faculty: The day before the final Student Symposium, the REU students take part in a faculty Luncheon/Presentation event where they practice their presentations for an audience of ME and IOE faculty and ERC students.

Final Research Symposium: Students are required to complete projects for presentation at the SROP symposium. To develop their academic and/or scientific writing skills, students must write a research abstract. The writing process can be an opportunity for the faculty mentor and student to discuss the project and clarify expectations. Students are also required to write a research paper and either give an oral presentation or prepare a poster, and present one or the other at the annual SROP Symposium.

\section{Sample Project}

Below is an example of the project proposals submitted by graduate students seeking REU students to work with them during the summer. Also included is an explanation of the structure of the research and a project timeline.

\section{FEA for the Virtual Turbine Blade Inspection Machine Proposal for REU (Research Experience for Undergraduates) Project, 2004}


Vijay Srivatsan

Graduate Student Research Assistant,

ERC for Reconfigurable Manufacturing Systems

Introduction: The Turbine Blade Inspection Machine is a 4-axis system that employs an optical sensor - Optimet's Conoprobe - to measure the form (surface geometry) of a turbine blade. The sensor is mounted on an XYZ motion stage and the turbine blade is mounted on a $360^{\circ}$ rotary stage. The sensor is capable of measuring the distance between itself and a point on the turbine blade surface. By a combination of the movement of the sensor in the XYZ axes and rotation of the turbine blade on the rotary stage, distance measurements on a cloud of points on the entire surface of the turbine blade can be measured and the surface geometry calculated.

As in all systems that involve motion stages, there are many factors that affect the errors of the measurement. Some are inherent motion stage errors such as pitch, yaw, roll and positional errors of each individual stage. Others, such as vibration and errors due to thermal effects, are errors that occur on the system as a whole. Using a CAD system with ProE as the backbone, a virtual machine has been built where the effect of these errors on the final measurement accuracy has been simulated. So far, errors that arise from the motion stages have been effectively simulated.

In this REU project, the errors due to the dynamic motion of the system and the errors due to environmental/ thermal effects will be explored and incorporated in the simulation by means of a Finite Element Analysis (FEA).

\section{Project Goals}

\section{Thermal Analysis}

Using any of the standard solid model packages, such as Ideas, Unigraphics or ProE, a solid model of the entire Turbine Blade Inspection Machine (BIM) will be built. This solid model will then be used for a finite element analysis on ANSYS.

Various situations will be tested, for the thermal analysis on the finite element model. The results from these models will give the position errors on the sensor and the blade. These results will then be fed into the simulation on the Virtual $\mathrm{BIM}$ in order to predict the errors on the measurement (of the surface geometry).

\section{Dynamic Analysis}

The solid model created in the thermal analysis can be used to conduct a dynamic FEA on the model. This comprises two aspects: The effect of environmental vibration and the vibrations caused by stage motion. As in the thermal analysis, the results from this FEA will be used to predict measurement errors on the simulation. 


\section{Deliverables}

Physical Outcomes

- A thermal FEM that will feed values of deflections due to thermal effects to the virtual machine.

- A dynamic FEM that will feed values of deflections due to dynamics to the virtual machine.

- Documentation and evaluation of the analysis.

The REU students will work closely with a Graduate Student mentor and a post doctoral researcher to accomplish these goals. The completion of this project will be a valuable contribution to the virtual BIM.

\section{Intellectual Outcomes}

The REU students will gain general experience on manufacturing technologies and RMS as a result of working on this test-bed project, as well as interaction with other REU teams. The students will also gain the following:

- Knowledge about solid modeling and FEA packages which are valuable skill sets for both industry and academic research.

- Knowledge about visual $\mathrm{C}++$.

- Machine design.

- A general overview of metrology, reverse engineering, control systems and optical technologies.

- The students will gain experience on organized research, which involves the ability to communicate ideas through scientific writing and presentations.

- Project management skills/effective time management, project planning.

- Team work: inter-team and intra-team interaction to achieve the goals of the project.

\section{Proposed Schedule}

Week $1 \& 2 \quad$ Learn and get acquainted with solid modeling packages

Week $3 \quad$ Build the solid model

Week 4 \& $5 \quad$ Learn and get acquainted with ANSYS

Week $5 \quad$ Create a FEM of the solid model and set up parameters

Week $6 \& 7$ Run thermal analysis on various BCs (TBD)

Week 8 \& $9 \quad$ Run dynamic analysis

Week $10 \quad$ Formal report and presentation

\section{List of Participating Schools}


Since the beginning of the REU program in the ERC/RMS we have had student participants from thirty-two different colleges and universities. Those schools are listed below.

\section{Universities Represented in the ERC/RMS REU Program - 1997 - 2004}

\author{
Alabama A\&M University \\ Cheyney University \\ Clark Atlanta University \\ Delaware State University \\ Dillard University \\ East Central Oklahoma University \\ Eastern Michigan University \\ Fisk University \\ Georgia Tech \\ Howard University \\ Jackson State University \\ Mississippi Valley State University \\ Morehouse University \\ Morgan State University \\ New Mexico State University \\ North Carolina A\&T University
}

\author{
Oklahoma State University \\ Polytechnic University of Puerto Rico \\ Saginaw Valley State University \\ San Francisco State University \\ Southern University \\ Spelman College \\ Sweetbriar College \\ Tougaloo University \\ Tuskegee University \\ UC Los Angeles \\ UC Riverside \\ University of Maryland at Baltimore \\ University of New Mexico \\ University of Puerto Rico at Mayaguez \\ Woodbury University \\ Xavier University
}

\section{Outcomes from Surveys}

The formal evaluation survey that was given to the students at the end of the 2004 program proved that they were extremely satisfied with their student and faculty mentors as well as with their research projects. They indicated overwhelmingly that they put high value on the Friday weekly progress meetings. They were also very satisfied with the coordination of efforts between the REU program and the Rackham SROP program. On a scale of 1 to 10 the students ranked both of the following questions at 8.8:

- Please rank to what extent the program met your expectations?

- Please rank to what extent you believe this research experience may help you in your future schoolwork, internships, graduate school?

The students all felt that the REU research experience will have the biggest impact in graduate school and in the workplace.

Answers to some of the open ended questions were:

- Learned new skills and technologies

- This experience makes me a stronger candidate for graduate school

- Helped me network

- I was exposed to a lot of geniuses!

- I was able to see how a premier institution operates.

\section{Summary of REU Student Participation by Year}


Figure 2 shows the impact that the REU program has had on applications, offers of admission and actual attendance in graduate school at the University of Michigan .

Those in bold type are currently enrolled in graduate programs at $\mathrm{U}$ of $\mathrm{M}$ or have recently finished a graduate degree at $\mathrm{U}$ of $\mathrm{M}$.

\begin{tabular}{|c|c|c|c|c|c|}
\hline Year & $\begin{array}{c}\text { ERC } \\
\text { Year }\end{array}$ & $\begin{array}{c}\text { \# of REU } \\
\text { Participants }\end{array}$ & $\begin{array}{c}\text { \# of REU } \\
\text { Participants } \\
\text { Applied to } \\
\text { UM }\end{array}$ & $\begin{array}{c}\text { \# of REU } \\
\text { Participants } \\
\text { Attending } \\
\text { UM }\end{array}$ & $\begin{array}{c}\text { \# of REU } \\
\text { Participants } \\
\text { Graduated } \\
\text { UM }\end{array}$ \\
\hline & & & & & \\
\hline 1997 & 1 & 3 & 1 & 1 & 0 \\
\hline 1998 & 2 & 4 & 1 & 0 & 1 \\
\hline 1999 & 3 & 4 & 0 & 0 & 0 \\
\hline 2000 & 4 & 12 & 0 & 0 & 0 \\
\hline 2001 & 5 & 9 & 2 & 1 & $*$ \\
\hline 2002 & 6 & 9 & 3 & 1 & $*$ \\
\hline 2003 & 7 & 13 & 5 & 2 & $*$ \\
\hline 2004 & 8 & 6 & $*$ & $*$ & $*$ \\
\hline
\end{tabular}

Figure 2

*Too soon for statistics.

1997 - Ronald Grover, PhD candidate in Mechanical Engineering, $\mathrm{U}$ of $\mathrm{M}$ 1998 - Kelly Nash, MS Physics, May 2003, U of M

2001 - Naomi Martinez, Working on MS in Math - U of M

2001 - Thomas Hatch, Applied to Biomed Eng U of M - Withdrew Application 2002 - Manli Li, PhD student in EECS - UC Santa Barbara 2002 - Lina Kim, PhD student in Mechanical Engineering - UC Santa Barbara 2002 - John Rigeur - Applied Aerospace Eng U of M - Not Admitted 2002 - Beth Miller - MS Student Mechanical Engineering - U of M 2002 - Krystle Lemon - MS student in Computer Science - Missouri State U 2003 - Kagya Amoako - PhD Student in ME - U of M - ERC/RMS 2003 - Betsabe Rodriguez - Applied IOE U or M 2003 - Leonard Lightfoot - Applied EE - U of M 2003 - Deandre Cole - Applied EECS - U of M 2003 - Shaton Sanderson - MS Student in Info Sys - U of M

There are no reported recruitment statistics available from other REU programs. However, the SROP program in which our students participate has had impressive results. Of the 9,331 students who have participated in CIC summer programs (which includes the ERC/RMS Research Experience for Undergraduates students), 952 have earned graduate degrees. 100 have Ph.D.'s, 625 have measter's degrees and 227 have professional degrees. You can see from Figure 3 the increase in participation that occurred since the beginning of the program in 1986 and 2004. 
Figure 3

SROP (CIC) Students by Year and Host Institution: 1986 and 2004

\begin{tabular}{|c|c|c|c|}
\hline University & 1986 & 2004 & Total \\
\hline & & & \\
\hline University of Chicago & 4 & 18 & 493 \\
\hline University of Illinois & 5 & 58 & 647 \\
\hline Univ of IL/Univ of Chicago & 9 & 85 & 1300 \\
\hline Indiana University & 5 & 0 & 359 \\
\hline Indiana Univ/Purdue Univ & 0 & 32 & 282 \\
\hline University of Iowa & 2 & 19 & 377 \\
\hline University of Michigan & 13 & 54 & 949 \\
\hline Michigan State University & 9 & 57 & 1119 \\
\hline University of Minnesota & 0 & 23 & 432 \\
\hline Northwestern University & 4 & 23 & 343 \\
\hline Ohio State University & 15 & 22 & 632 \\
\hline Pennsylvania State University & 0 & 39 & 341 \\
\hline Purdue University & 9 & 41 & 711 \\
\hline University of WI Madison & 1 & 22 & 653 \\
\hline University of WI-Milwaukee & 0 & 20 & 286 \\
\hline TOTALS & $\mathbf{7 6}$ & $\mathbf{5 1 3}$ & $\mathbf{8 9 2 4}$ \\
\hline
\end{tabular}

\section{Future Plans}

The REU program has been so successful for the ERC/RMS that we do not plan to make any significant changes in it's structure in the foreseeable future. We will continue to recruit in the same manner as in past years. The group projects, the unique mentoring system that we have developed and the graduate student proposal contest have proven to be so successful that we do not think it appropriate to make any changes.

We will continue to partner with the very successful SROP summer program on campus and be a part of the Big 10 CIC program. The strength of this combination of counterparts has increased the number of minority students seeking Ph.D.'s. According to Shirley M. Malcom, Director of Education for the American Association for the Advancement of Science, “...(these programs) are a major contributor to the Ph.D. minority pipeline."

\section{Summary}

Building upon the successful history of the REU program, the Center applied for, and recently received, a grant for a second REU program in the Center. This REU will be with Florida A\&M University (FAMU) exclusively and will bring six students from that campus to the University of Michigan for the 8-week summer experience. The unique feature of the FAMU/REU will be that the participants will commit to two summers on the $U$ of $M$ campus to give us a longer period of time to recruit them to Michigan for their graduate studies. The FAMU/REU will run in tandem with the original program and will add two more projects to the overall combined program. 
The new programs, along with the original REU program, will focus on successful and mutually beneficial partnerships between $U$ of $M$ faculty and students from other universities. The ERC will utilize all of these programs to recruit top graduate students by enabling them to benefit from the wealth of research activities at Michigan.

YORAM KOREN, Director of the NSF Engineering Research Center for Reconfigurable Manufacturing Systems, and also Paul G. Goebel Professor of Engineering at the College of Engineering, U of M. His most significant contributions have been in the field of manufacturing automation and machine tool control. Member NAE, Fellow ASME and SME, a Senior Member of IEEE, and an active member of CIRP.

ELIJAH KANNATEY-ASIBU, JR., Associate Director for Education, NSF Engineering Research Center for Reconfigurable Manufacturing Systems, and also Professor, Department of Mechanical Engineering, U of M. Distinguished awards from ASME, American Foundrymen and American Welding Society.

Research includes multi-sensor monitoring of manufacturing processes and laser processing of materials.

LENEA HOWE, Education Coordinator for the Engineering Research Center for Reconfigurable Manufacturing Systems, received her BFA in Fine Arts and Education from the University of Michigan. She has 15 years experience in all aspects of graduate recruitment and undergraduate summer research program administration.

"The work was supported primarily by the Engineering Research Centers Program of the National Science Foundation under Award Number EEC-9529125."

\section{References}

Capsouras, J. L., "Laying a Foundation for the Future: Building Your Home in the Academy", SROP Faculty Mentor Handbook, University of Michigan, 2004.

Jacobson, Jennifer, "Opening the door to a Doctorate", The Chronicle of Higher Education, August 13, 2004.

Council on Competitiveness. "World Class Workforce. The BEST Initiative,"

http://www.compete.org/wd//best.asp

University of Maryland, Baltimore County, "Meyerhoff Graduate Fellows Program," http://www.umbc.edu/meyerhoff/Graduate/

UCLA Center for Excellence in Engineering and Diversity, http://www.ceed.ucla.edu/main.htm 